\title{
UNINCORPORATED NON-PROFIT ASSOCIATIONS IN CONTRACT: A NEED FOR REFORM VICTOR LIRETTE*
}

\begin{abstract}
The law relating to unincorporated non-profit associations has not developed with any consistency. This has resulted in a morass of legal theory which desperately fails to satisfy the need for clarity in this area. The author discusses the prevailing theories relating to the legal status of unincorporated non-profit associations. He concludes by recommending statutory intervention as the means of reform that will best alleviate the present inconsistencies in the law.
\end{abstract}

\section{INTRODUCTION}

\section{A. THE PROBLEM}

Unincorporated non-profit associations are pervasive in contemporary society. ${ }^{1}$ They encompass a wide gamut of human activities, ranging from neighbourhood social clubs to large scale multi-national charitable organizations, and either directly or indirectly they influence our daily lives. Occupying, as they do, such a large sphere of influence, unincorporated non-profit associations and their rights vis-à-vis third parties undoubtedly provide issues of considerable legal importance.

A difficult problem is, "what is the position of a party seeking a legal remedy from an unincorporated non-profit association for a breach of contract?" The solution has, to a large extent, been left up to the common law to determine. Unfortunately, the answer given has lacked theoretical consistency. The common law response has been a piecemeal effort which fails to form a comprehensive strategy capable of dealing with all of the problems that arise between third parties and unincorporated non-profit associations in contractual relationships. It has resulted in a legal morass where third parties can be virtually without remedy.

\section{B. THE FRAME OF REFERENCE}

It is important to clarify what is meant by the term "non-profit associations." A non-profit association is not restrained from making a profit." "Many non-profits in fact consistently show an accounting surplus." 3 Rather, the primary distinction between a non-profit and a for-profit organization is the ability each has to distribute their profits

- B.Ed., LLB.; presently articling with the firm of Reynolds Mirth \& Cote in Edmonton. The author wishes to thank Mr. Baz Edmeades and Professor P.J.M. Lown for their perceptive insights and invaluable comments at various stages in the preparation of this article. All errors, omissions and defects are, of course, solely the responsibility of the author.

1. Although there is a paucity of statistical data on non-profit associations in Canada, there is no reason to believe that there exists any great disparity between the situation in Canada and that in the United States where "recent surveys indicate that perhaps as many as onefifth of all corporations in the United States are non-profit, and that this proportion is steadily growing" H.B. Hansmann, "Reforming Non Profit Corporation Law"(1981) U. Penn. L. Rev. 497 at 500 . If we assume that non-profits make up the same ratio of unincorporated associations it is a sizeable number. It is well accepted that there are a considerable number of unincorporated non-profit associations with a significant impact on society. H.A.J. Ford, Unincorporated Non-Profit Associations (1959) XIX.

2. H.B. Hansmann, "The Role of Non-Profit Enterprises" (1980) 89 Yale L. Rev. 835 at 838.

3. Id. at 838 . 
(earnings above expenses). A for-profit axiomatically distributes its profits to its members. It has but one purpose, which is the enrichment of its membership. Conversely, a non-profit association may be the vehicle of any one of innumerable purposes, save one - the enrichment of its members. ${ }^{4}$ In a non-profit, all profit must be dedicated to the purpose for which the association is formed. ${ }^{5}$ Therefore, any association that is dedicated to a purpose other than profit, and prohibits the distribution of assets to its members, is a non-profit association. ${ }^{6}$

This paper focuses on the legal problems experienced in contracts between unincorporated non-profit associations and third parties. It does not deal with unincorporated for-profit associations, which are statutorily regulated by the Partnership Act applicable to the jurisdiction in which the for-profit association is located. Unincorporated for-profit associations are not governed by the common law rules applicable to unincorporated non-profit associations.

\section{THE COMMON LAW}

\section{A. UNINCORPORATED ASSOCIATIONS LACK LEGAL STATUS}

The problems in the law regarding unincorporated non-profit associations derive primarily from the classic view that "an incorporated company is a legal person separate and distinct from the individual members

4. Hansmann, "Reforming Non-Profit Corporation Law", supran. 1 at 511

5. "It should be noted that in any event 'profits' may be distributed indirectly through salaries and other intangible benefits that may accrue to members. These indirect distributions may be made without violating the principles underlying the non-distribution constraint." $\mathbf{R}$. Dimieri and S. Weiner, "The Public Interest in Governing Boards of Non-Profit Health Care Institutions" (1981) 34 Vanderbilt L. Rev. 1029 at 1041.

6. It should be noted that in Alberta the statutory restrictions on the distribution of assets are for "incorporated" non-profit associations only, and that merely current distribution constraints are provided for,ie. only while the organization is active does the legislation prevent the distribution of assets to members. There are no terminal distribution constraints upon the winding-up of incorporated non-profit associations. A good example is the Societies Act R.S.A., 1980 c. S-18 s.4(1) which states:

No society shall have a capital divided into shares or declare any dividend or distribute its property among its members during the existence of the society.

No provision is made to prevent the membership of the organization from receiving the assets on dissolution.

The lack of a terminal distribution constraint may cause little worry where one is dealing with an organization dedicated to the mutual benefit of its members (clubs), because in such a case the members who receive the assets on dissolution are the intended beneficiaries. But, in the case of public benefit non-profits where the members are not the intended beneficiaries, ie. Heart Fund, it would be appalling if the present members could wind-up the association and appropriate the assets to their own purposes. Reform in this area is definitely needed.

With regard to unincorporated non-profits the situation is dealt with by the common law which has characterized unincorporated non-profit property as a hybrid between joint property and corporate property. A member has the interest of an ordinary joint tenant, but is without the right to sever the tenancy at his will or to partition his interest when he leaves. In essence the law surreptitiously creates a purpose trust. It cannot belong to the association because the association is not a legal entity yet in equity it does not belong to the members because it was not intended for them. Only if all the members agree can the property be divided. Therefore, short of unanimity, the common law provides for current and terminal distribution constraints.

Note: property of an unincorporated non-profit association is discussed more fully on pages 7 and 8 of the text. 
of the company whereas an unincorporated company has no such separate existence and is not in law distinguishable from its members." The logical result of this is that any third party claiming rights against an unincorporated association must claim them from the individual members and cannot proceed directly against the assets of the association because "the funds belong to all the members in equal shares: hence to reach them he has to show all the members of the society are liable to him"' ${ }^{8}$ The unincorporated non-profit association is not viewed as a legal entity; it is devoid of corporate status: ${ }^{9}$

This is especially misleading to third parties, because to the outside world they seem to possess just as much collective capacity as any corporation, they appear to occupy premises, own funds, act through duly appointed officers, describe themselves by a collective name and purport to engage in transactions with tradesmen and others under that name. It is only when such transactions give rise to legal disputes and it is desired to institute proceedings, that it emerges that the collective name is merely a facade concealing, but not altering the hard legal fact that, in law, the association is the mere sum of its individuals, without any collective capacity to sue or be sued as such.

The unincorporated association cannot sue or be sued in its own name because attempts to do so would be inconsistent with the common law's denial of its corporate status and the belief that it has no rights apart from those of its individual members. ${ }^{10}$

\section{B. THE AGENCY ANALYSIS}

1. THE PARTIES TO THE CONTRACT

The traditional analysis utilized by the court to permit a third party a remedy against an unincorporated association has been to apply agency principles. ${ }^{11}$
Generally courts have refused to regard an unincorporated non-profit association as a right and duty bearing unit distinct from the individuals composing it. This has meant that what might have been a question whether a contract was made on behalf of an association as an entity is, in law, generally treated as a question whether the contract was made by or on behalf of individuals. . . . Attribution of the contract to those in- dividuals who did not themselves take part in its formation is said to depend on or- dinary agency principles.

It is an important question of fact in any contractual action against an unincorporated association to determine exactly who the parties to the contract are.

Where the third party was unaware that the association was unincorporated or that it lacked corporate personality, the court has tended to vacillate on the categorization of the parties to the contract. ${ }^{12}$

On rare occasions this has led a court to deny the existence of any contract at all, but this is an unusual result and in the great majority of cases those members of the committee who have actually made the contract or who have authorized or ratified it are made personally liable.

7. 6 Halsbury's Laws (3d) 11.

8. K.F. Keeler, "Contractual Actions for Damages Against Unincorporated Bodies" (1971) 34 Mod. L. Rev. 615. See also H.A J. Ford, supran. 1 at 93 and 126.

9. D. Lloyd, “Actions Instituted By or Against Unincorporated Bodies" (1912) 12 Mod. L. Rev. 409 at 410

10. "Attempts to do so were variously defeated on the grounds that no legal capacity to sue, misnomer, non joinder of parties, or failure to give Christian or ancestral names." Note, "The Right of Unincorporated Associations to Sue in the Association Name" (1951) 39 C.L.R. 264 at 265.

11. H.A.J. Ford, supran. 1 at 51.

12. K.F. Keeler, supra n. 8 at 617. See also H.A.J. Ford, supran. 1 at 84-87. 
Where the court has denied the existence of a contract ${ }^{13}$ they have tended to do so on the reasoning that the agent has contracted on behalf of nonexistent principals, and there is no rule that makes the agent personally liable in such situations. ${ }^{14}$ H.A.J. Ford maintains the better view is that the agent should always be found a party to the contract, either because he is in breach of an implied warranty that he had authority, or, "that the 'agent' must be held liable on the contract in the absence of anyone else being bound", 15 because it would be inequitable to deprive the third party of all remedy, when both he and the agent thought they were contracting. ${ }^{16}$ Also, any member that authorized, performed or ratified the contract should be liable as a principal to the contract. ${ }^{17}$

\section{THE GLOSS OF LIMITED LIABILITY - REMEDY RESTRICTED TO THE COMMON FUND}

Although a traditional agency analysis would make any principal jointly and severally liable for all damages arising out of a contract, ${ }^{18}$ this is not the case regarding a principal to a contract on behalf of an unincorporated non-profit association. A special rule has developed at common law with regard to clubs, that it is an implied condition of membership in any club that a member is not to be liable for any amount beyond the total of his subscriptions to the association. ${ }^{19}$ Lord Lindley stated in the seminal case of Wise v. Perpetual Trustee Company Limited: ${ }^{20}$

Clubs are associations of a peculiar nature. They are societies the members of which are perpetually changing. They are not partnerships; they are not associations for gain; and the feature which distinguishes them from other societies is that no member as such becomes liable to pay to the funds of the society or to anyone else any money beyond the subscriptions required by the rules of the club to be paid as long as he remains a member. It is upon this fundamental condition, not usually expressed but understood by everyone that clubs are formed.

This rule has subsequently been extended to cover other unincorporated non-profit associations. ${ }^{21}$ The result is that, apart from the agent, a third party will not be able to attach liability to any of the members greater

13. Jones v. Hope (1880) 3 T.L R. 247, Holmann v. Pullin (1884) Cab. and E11. 254, see also H.A.J. Ford, supra n. 1 at 51

14. K.F. Keeler, supran. 8 at 617.

15. H.A.J. Ford, supra n. 1 at 84.

16. Bradley Egg Farm Limited v. Clifford [1943] 2 All E.R. 378 per Scott L.J.

17. K.F. Keeler, supran. 8 at 617.

18. Id. at 615 .

19. Wise v. Perpetual Trustee Company, Ltd. [1903] A.C. 139, J.S. Josling and L. Alexander, The Law of Clubs (2d ed., 1970) 76. See also H.A.J Ford, supra n. 1 at 17 and K.F. Keeler, supra n. 8 at 615 .

20. [1903] A.C. 139 at 149.

21. Bradley Egg Farm Limited v. Clifford [1943] All E.R. 378, Ex parte Goodard; re Faldey [1946] St. R. (N.S.W.) 289, see also A.H. Oosterhoff, "Indemnification of Trustees: The Rule in Hardoon v. Belilios"'(1977-78) 4 E.T.Q. 180 at 189 and H.A.J. Ford, supra n. I at 57. Where a for-profit unincorporated association would not have limited liability an "association ... formed for the moral, benevolent, social, or political purposes rests on a different basis. The individual liability of the members for contracts made by the association, or its of ficers for committees, depends upon the application of the principles of law of agency; and authority to create such liability will not be presumed or implied from the existence of the general power to attempt to or transact the business or promote the objects for which the association was formed, except where the debt contract is necessary for its preservations." McCabev. Goodfellow 30 N.W. 728 at 730. 
than their subscriptions to the assets of the association, because the agent lacked the authority to pledge any further liability on behalf of the members. A complainant in contract not only desires to, but therefore must, attach liability to the fund of the association or risk being without a remedy. If he cannot attach the fund, his only recourse is against the agent (in most cases the management committee), whom the courts find has pledged his own credit. ${ }^{22}$ (The committee members who contract as agents for the association are not protected by the limited liability rule established in the cases. ${ }^{23}$ The rule is only implied and the courts find it is rebutted by the agent because he gives an implied warranty of his authority). ${ }^{24}$ Unless the committee members can rebut the limited liability of the general membership by proving that every member authorized the extension of credit or that the rules of the club permitted them to extend the members' liability beyond their subscription, ${ }^{25}$ then only the committee will be liable for any amount exceeding the assets of the association. ${ }^{26}$ It is therefore incumbent upon a complainant to attach liability to the fund.

\section{PROCEDURAL ROADBLOCKS PREVENT ATTACHMENT OF COMMON FUND}

An inherent problem in the agency analysis, deriving from the unique nature of an unincorporated association's property, of ten serves to disentitle a legitimate complainant from redress on a mere procedural ground. Once the court determines that a contract exists, and it is clear the cause will necessitate attaching the association's assets, there remains the procedural difficulty of gaining access to those assets.

A hybrid type of property exists in an association's assets. The property is dedicated to the association's purpose, yet it cannot be owned by the association as a separate legal entity. The result is that it is owned jointly by all members, and collectively the members have the right to absolute ownership of the entire property, but no member has a distinct share which he may call his own. ${ }^{27}$ Upon death the interest of any member passes to the survivors in the association. A member has the interest of an ordinary joint tenant, but lacks the right to sever the joint tenancy at his will or to partition his interest in the tenancy when he departs. It is only with the consent of all members that association property can be liquidated and the assets distributed amongst the members. ${ }^{28}$ Therefore a claim against one member of the association, or many, cannot form a claim on the association's property. The property is dedicated to a pur-

22. T.G. Matthews, "Procedures on Borrowing and Obtaining Credit by Unincorporated Associations" (1967) 5 U. Qld. L.J. 392 at 397 . See also K.F. Keeler, supra n. 8 at 618.

23. Flemyng v. Hector (1936) 2 M\&W 172, Wise v. Perpetual Trustee Company, Ltd. [1903] A.C. 139, Bradley Egg Farm v. Clifford [1943] All, E.R. 378.

24. T.G. Matthews, supra n. 22 at 398, see also infra n. 40.

25. Id..

26. K.F. Keeler, supra n. 8 at 618 .

27. T.C. Williams, "Club Trustrees' Right to Indemnity; A Criticism of Wise and Perpetual Trustee Company Limited" (1903) 19 L.Q. Rev. 386 at 391.

28. Id.. 
pose when the member enters the association, and subject to the agreement of all membership, it must remain dedicated to that purpose. ${ }^{29}$ The ramification of this interpretation is the requirement that any comnant has to join all association members before he can recover from the association's assets. ${ }^{30}$

It is often an impractical, if not impossible, remedy for an aggrieved party to join all the members of a defendant association. It would require every member to be named and given the full rights of a separate defendant, including independent representation and legal costs. ${ }^{31}$ If the association is of any size at all it may be prohibitively expensive or virtually impossible for the claimant to find and join all the members to the action. ${ }^{32}$ The only practical solution open to the complainant in many cases will be to institute a representative action. ${ }^{33}$

The representative action is not a panacea for a third party attempting to attach liability to an unincorporated non-profit association's funds. The crux of the Rule concerning representative actions is the requirement that "numerous persons have a common interest". This has been strictly interpreted by the courts to mean that the parties must have the "same" interests. ${ }^{34}$ "Similar" interests will not be sufficient.

Most unincorporated associations exist in a state of interchangeable fluctuating memberships. There is a continual changeover of members, but the funds, dedicated to a purpose, remain intact separate and apart from the members and untouched by any alteration in the composition of the association. There is in effect perpetual succession in an unincorporated non-profit association. The assets exist independent of the membership as long as the association remains active. This creates insurmountable problems when placed in the context of the agency analysis that the courts utilize in interpreting unincorporated association con-

29. H.A.J. Ford, supra n. 1 at 50. Ford presents a thesis premised on the theory that the only way of accounting for the treatment of unincorporated non-profit association property "is to regard it as being dedicated to a purpose".

30. For a short discussion on the theoretical basis of the ownership of unincorporated nonprofit associations' property see B. Green, "The Dissolution of Unincorporated NonProfit Associations" (1980) 43 Mod. L. Rev. 626 at 627-628.

31. K.F. Keeler, supra n.8 at 411.

32. H.A.J. Ford, supran.1 at 94 .

33. Id. at 94-95. Representative actions originated in the Court of Chancery as a response to the cumbersome requirements of joinder. Where the parties were numerous and joinder impractical, a representative action was allowed. However, prerequisite to a representative action were the conditions that representation not prejudice the represented party in any way and that the members of the class being represented have the same rights. These common law guidelines are codified in the Alberta Rules of Court Rule 42 which reads "Where numerous persons have a common interest in the subject of an intended action, one or more of those persons may sue or be sued or may be authorized by the court to defend on behalf or for the benefit of all".

34. In England, British Columbia and Ontario, their Rule equivalent to our R.42 states that the parties to the action must have the "same interest", not a "common interest". The Alberta Supreme Court however in Goodfellowv. Knight (1977) 2 Alta. L.R. (2d) 17 at 21 stated:

... the decisions from Ontario, British Columbia and England are applicable to the interpretation of Alberta, R.42.

In coming to this conclusion they relied upon A.E. Osler \& Co. v. Solman [1926] 4 D.L.R. 345 at 349 where Orde J.A. used the term "same interest" synonomous with the term "common interest". 
tracts. The agency analysis results in the need to use a representative action in order to reach the common fund but a representative action requires that all defendants have the same rights vis-à-vis the third party. If even one member of an association has joined since the time the contract was entered into and before the time the action is commenced then the contract cannot be enforced by way of a representative action. ${ }^{35}$

He [third party] will be faced with the fact that members who have joined after the date of the contract will not have been able to have authorized it at the time it was made; so, even in the unlikely event of their having ratified it, or been able to ratify it (in light of the rules that only a person on whose behalf a contract is purported to be made may ratify it and that principal may be ascertainable at the date of the contract) they will clearly have defences different from those of the persons who were members at the date the contract was made.

In effect a third party will be disentitled from a remedy, in many cases, on a procedural ground having nothing whatsoever to do with the merits of the case. He will be unable to take a representative action due to a change in membership and it is impossible or impractical for him to join all the members of the association.

\section{INADEQUACY OF AGENCY ANALYSIS}

The inadequacy of the agency analysis derives from its failure to recognize and deal with the fact that the law regarding unincorporated associations no longer reflects the traditional catch phrase definition that an association has no rights separate and apart from its members. The theoretical underpinnings of unincorporated non-profit association law have not been consistently developed. This has resulted in the existence of a morass of legal theory which desperately fails to satisfy the demands of the situation. The common law has given the unincorporated association many of the trappings of corporate bodies (limited liability, perpetual succession) while simultaneously avowing adherence to the traditional view of the association as a group of separate individuals with distinct legal rights. The problem is that an unincorporated non-profit association either is, or is not, a separate legal entity. If it is not, then an agency analysis should be taken. If it is, then it should be able to be sued directly. It is theoretically inconsistent to simultaneously view the association as a group of individuals and yet restrict its liability to the fund. By restricting liability the court is recognizing the separate legal existence of the association and that the obligations of the association are not the personal obligations of the members. Yet in the same breath the court is denying the existence of the entity to which it has given life. In order to be consistent the laws must either delimit the liability of members, ${ }^{36}$ or recognize the separate legal existence of the association and allow it to sue or be sued in its own name ${ }^{37}$ Anything short of this results in the conflict of two antithetical legal theories and inequities to the parties concerned; legitimate claims are lost on procedural grounds rather than merit.

35. K.F. Keeler, supran. 8 at 616.

36. T.C. Williams, supra n. 27.

37. W.A. Sturges, "Unincorporated Associations as Parties to Actions" (1923-24) 33 Yale L.J. 383. 


\section{THE KEELER ANALYSIS}

\section{A. THE THEORY}

Keeler proposes a fruitful analysis, which attempts to remain concordant with the present common law interpretation of unincorporated nonprofit associations. ${ }^{38}$ The analysis tries to reconcile the divergent theories of unincorporated association law, and to a large degree it succeeds.

Keeler has suggested that the proper method for a claimant seeking a remedy from an unincorporated association is to sue the management committee directly as principals to the contract, and to subrogate the claim to the committee's right of indemnity from the association's fund. This analysis presupposes the courts finding the contract to have been made by the third party with the management committee, and the committee having unlimited liability. In the majority of cases these suppositions will be appropriate because the courts will find a contract to have been made with the members of the committee and those who authorized their act. ${ }^{39}$ Also, the committee's liability is not usually viewed as limited by the courts. ${ }^{40}$ The central question which arises regarding the Keeler analysis is whether the courts will find that an unincorporated association's management committee has the right of indemnification from the general fund.

\section{B. DOES MANAGEMENT HAVE INDEMNITY RIGHTS?}

An unincorporated association at common law is capable of owning its own property through trustees and of suing and being sued through them on matters pertaining directly to that property, without having to join the members of the association. ${ }^{41}$ Management, however, is of ten separate from the trustees. It is clear that the trustees of the association's assets will have a right of indemnification from the assets for any loss they properly incur within the scope of the trust. The right of indemnity not only covers out-of-pocket expenses incurred by a trustee in the management of the trust, but also encompasses any liability he may have incurred in the proper execution or maintenance of the trust. ${ }^{42}$ Hardoon v. Belilios ${ }^{43}$ has extended the indemnification principle so that a trustee is not only entitled to be indemnified from the trust fund but also has a personal claim

38. K.F. Keeler, supra n. 8.

39. Bradley Egg Farms v. Clifford [1943] All E.R. 378, K.F. Keeler, supra n. 8 at 617.

40. T.G. Matthews, supra n. 22 at 394 . The personal liability is usually found by the courts on the basis of breach of implied warranty of authority by the agent. "Where one assumes to act as agent for another, he impliedly represents that his principal has existence, and that he has authority to act for him, and, if either of these things be false the agent he becomes personally liable." Little Rock Furniture Manufacturing Company v. Kavanaugh 164 S.W. 289 at 293 . It should be noted that the case went on to state that where an agent "makes full disclosure of fact constituting his authority, as when he shows the other party the power of attorney, or letters of instructions under which he acts, the question of his authority becomes a mere question of construction or of law and no warranty of sufficiency of authority can be implied." Id. at 293.

41. D. Lloyd, supran. 9 at 421.

42. A.H. Oosterhoff, supran. 21 at 182-3.

43. Hardoon v. Belilios [1901] A.C. 118 at 124. See also T.C. Williams, supran. 27 at 124 and H.A.J. Ford, supran. 1 at 70-75. 
against the assets of the cestui que trust himself, as long as the cestui que trust received the benefit of the act which incurred the liability. ${ }^{44}$

There is little direct authority for a management committee having a right of indemnity; this could be due to the fact that where there are insufficient assets in the fund it would be useless to argue indemnity, and where the common fund is sufficient to cover the breach the management committee would have paid the liability from the fund rather than risking personal liability. It would only be in the peculiar case where the complainant must attach the assets of both the common fund and the assets of the committee members in order to satisfy his claim, that the issue of indemnity would arise. The better view, it is submitted, is that the management committee does have a right of indemnity. As Keeler points out: ${ }^{45}$

In a normal case where there are both trustees and a managing committee it would be remarkable if those persons who are compelled to accept personal liability on the contracts of the association and have the power of managing the fund should have fewer rights against the fund than the trustees, whose function in these circumstances is almost wholly ministerial.

It should be noted that the theoretical basis of the indemnity right is equity: that no man should enjoy the advantage of property without suffering the attendant liabilities. ${ }^{46}$ This rationale would dictate a right of indemnity for management committees on the same rationale as trustees are indemnified by their cestui que trust and agents by their principals.

\section{IF INDEMNIFIED, TO WHAT EXTENT?}

\section{LIMITED LIABILITY-RESTRICTED TO THE COMMON FUND}

If it is accepted that committee members have a right to indemnity it must be noted that the extension of that right created by Hardoon v. Belilios ${ }^{47}$ to the personal assets of the beneficiaries would not apply to unincorporated non-profit associations because of Wise v. Perpetual Trustee Company Ltd. ${ }^{48}$

In general trust law a trustee has the right of indemnity against both the trust fund and the cestui que trust. The ef fect of Wise and subsequent cases is to limit the right of indemnification, with regards to unincorporated associations, to the fund of the association. ${ }^{49}$

There is in the nature of the transaction an implied bargain, unless the rules of the club provide to the contrary, that the members shall not as beneficiaries be liable to indemnify the trustees, and the trustees are taken to accept the office with knowledge of this condition.

Therefore, any liability over and above the amount of the association's assets will come to rest on the shoulders of the management committee for satisfaction.

\section{CRITICISMS OF WISE}

The decision in Wise has been severely criticised. ${ }^{50}$ It has been argued

44. A.H. Oosterhoff, supra n. 21 at 186, also H.A.J. Ford, supran. 1 at 73.

45. K.F. Keeler, supran. 8 at 620.

46. Supran. 43.

47. Id..

48. Supran. 20. See also H.A.J. Ford, supran. 1 at 77.

49. D.J. Hayton, Underhill's Law of Trust and Trustee (13th ed. 1979) 681.

50. A.H. Oosterhoff, supran. 21 at 188-189, T.D. Williams, supra n. 27 at 386. 
that the equitable extension of trust law created by Hardoon v. Belilios is appropriate to unincorporated associations because it would be inequitable for association members to accept the benefit of the contract without having to accept any liability beyond their subscriptions to the common fund: 51

\begin{abstract}
If the rule laid down in Wise v. Perpetual Trustee Company Ltd. be good law, what strange consequences might follow? Suppose trustees hold property for a club and heavy rates or taxes be imposed on the legal owners of the property, are the trustees to pay and the members to go Scot free? Suppose the trustees, without their own actual fault, but by negligence or misadventure of the committee's servant, were to incur some liability, as the owners of the club property, on the principles of Rylands v. Fletcher... These examples show what grave injustice may be suffered if the rule in Wise is to prevail and the trustees of the club property are to be excluded from the benefit of the sound principle established in Hardoon v. Belilios.
\end{abstract}

Although there is some merit to these criticisms, they are largely illfounded. The result of the Wise case is to give unincorporated associations limited liability, and in effect it is a partial recognition of the corporate existence of unincorporated associations. The majority of third parties do not differentiate between incorporated and unincorporated enterprises and do not intend to deal with the members of an unincorporated body individually..$^{52}$ To impose personal liability upon the management committee of an association, for any amount greater than the assets in the common fund, is not much greater an imposition than the duty placed on directors by company law, especially as it relates to contractual liability. It is a common law reiteration of a director's personal liability where he has acted without regard to the liquidity or solvency of his company, except that it is applied to the management committee of unincorporated associations. Only where the association is not liquid or solvent will a management committee member face liability.

It is asserted that the better view is: ${ }^{53}$

\begin{abstract}
... there is no reason why in relation to a stranger the committee should not accept liability as the law now requires. Members of the committee are in the best position not only to know all of the facts but also to take any action that may be necessary to protect all of the parties including themselves.
\end{abstract}

Equity is better served by the committee, which could protect itself, being held liable, rather than the member who is dependent upon the committee's execution of its fiduciary duty.

It must be acknowledged that the criticisms put forth have greater merit in terms of unincorporated non-profit associations established for the mutual benefit of their members, i.e. clubs. The focus of the criticisms is based on the ratio of Hardoon v. Belilios: no one should enjoy the benefits of property without incurring its liabilities. Even in a mutual benefit context, however, it is not inequitable to make only the committee responsible for obligations exceeding the common fund. It is important to realize that a club member's decision to remain a member is predicated upon the dues he is required to pay in order to enjoy the property. If the dues are unreasonably low in relation to the cost of the property, resulting in insufficient funds to pay the obligations arising

51. T.C. Williams, supra n. 27 at 397.

52. D. Lloyd, supran. 9 at 410.

53. T.G. Matthews, supran. 22 at 397. 
therefrom, then is it equitable to charge the membership with the difference because they have enjoyed the property? The answer, in this writer's opinion, is no! It is the negligence of the committee which has resulted in too small a subscription being levied. They were in the best position to determine what should be charged and what contracts should be entered into. The members' decisions to remain members are based on the original subscription price levied by the committee and they should not later become liable for a greater expense, when they may not have remained members had they been aware of the larger cost.

The limited liability of members, with all greater risk falling on the committee, it is asserted, is more attuned to the reality of the situation. To extend liability to the members would be a windfall to the creditors because they have no idea, in the majority of cases, who the members are, nor do they intend to deal with them individually. ${ }^{54}$ It is also suggested that creditors may be better protected by limited liability and in being able to collect from the fund because, one, it is the association and the fund they intended to deal with, and two, the common fund consists of subscriptions of past and present members, and also members who joined after the breach. It may, therefore, consist of more assets than would otherwise be available if the creditor went after only the current members at the time of contract. The expectations of all parties are more accurately reflected because, as aforementioned, the members usually do not expect any liability beyond their subscriptions nor do the creditors intend to deal with anyone other than the association. It would be a greater inequity to allow a creditor to seek compensation from present members because he would receive both the benefit of compensation from the fund, based on a corporate analysis, and a personal liability from the members at the time of breach, based on the view that an association is not distinct from its membership. An unincorporated association is, or is not, a corporate body and the creditors should not be allowed to collect on the basis of both.

If the law was theoretically consistent, giving easy access to the common fund by a third party, then the criticisms of Wise are illfounded. Wise is only inequitable in the theoretical mêlée that presently exists because the law as it stands serves to prevent the third party from access to the fund to which their remedy is limited. It is not inequitable because the committee would be liable for any amount greater than the common fund.

\section{INADEQUACY OF KEELER ANALYSIS}

The Keeler analysis is not the perfect solution. Earlier it was mentioned that any comprehensive solution would require adherence to a singular theoretical basis - either an unincorporated association is a corporate entity or a group of individuals, but not both. The Keeler analysis attempts to reconcile the theoretical dichotomy without altering the basic structure of the common law as it presently stands. It travels a considerable distance towards a solution but falls short due to the theoretical inconsistency of the two views which it permits to coexist.

First, the third party of ten intends to contract with the association but the association is not permitted to contract as a legal entity. The problem 
remains for the courts of determining who are the parties to the contract, or even if a contract exists. This is a problem which the indemnificationsubrogation analysis does nothing to solve.

Second, the effectiveness of Keeler's interpretation is also somewhat mitigated by the fact that a trustee's right of indemnification and therefore a creditor's right of subrogation is limited to acts performed within the trustee's scope of authority. "It has no application where a trustee has, contrary to the trust . . . incurred liabilities"; 55 nor does it protect a third party where a committee member has subsequently done something to disentitle himself. The creditor in such a case will be limited to claiming personally from the committee members who may be "men of straw". The Keeler analysis does not have a protection equivalent to the "indoor management rule" 56 of company law. Therefore, if the management committee has acted beyond the scope of its authority the claimant will be deprived of a remedy against the common fund, despite the fact he could not reasonably have been expected to have known the committee was acting outside of its powers. The inequity of this possibility is lessened by the fact that some committee members may disqualify themselves from their right of indemnification without the claimant being adversely affected as long as one committee member remains qualified. If one committee member is qualified the third party can subrogate his claim through the one member's right of indemnity and directly attack the fund for the entire amount. This will not, however, offer any solution where the committee has, as a whole, acted beyond its powers.

Third, although it was earlier asserted that it is preferable that the committee be held liable for all amounts claimed exceeding the common fund, this view must be tempered with some moderation: moderation which the indemnification-subrogation analysis does not provide for. It was aforementioned that a committee's liability for amounts greater than the common fund was a common law analogy to a director's liability to his company. It is not however a perfect analogy. The analogy is flawed because the common law lacks theoretical consistency.

The Keeler analysis has chosen to follow the common law which interprets a contract as being made with the individual committee members while it simultaneously recognizes the corporate existence of the general membership and totally limits their liability. It would be better to recognize that both the committee and the membership are part of the corporate entity and that it is only where the committee breaches its fiduciary duty that it should be liable, or that the contract is with all of the members and the committee as individuals and that they are all liable.

54. D. Lloyd, supra n. 9 at 410.

55. T.C. Williams, supra n. 27 at 686.

56. "The person dealing with the company is not obliged to enquire into the internal workings of the company, and is entitled to assume that any necessary procedural preliminaries have been properly performed unless he has or ought to have, actual knowledge to the contrary." Institute of Law Research and Reform Report No. 36, "A Proposal for a New Alberta Business Corporations Act" at 38. 
Under Keeler's theory the committee is liable for everything greater than the assets of the association, even if it relied on information which it would be reasonable to rely upon. Where the committee has not been negligent or purposefully breached its fiduciary duty there is no reason it should be liable any more than the members. If the members' liability is limited the directors' liability should be based on fiduciary duty, not on agency. The fact that the members have limited liability and the committee remains liable for the entire amount, no matter how reasonable its actions, is again a confusion by the common law of the theoretical basis upon which unincorporated non-profit association law rests.

The corporate theory of unincorporated non-profit associations, it is submitted, is more attuned to the reality of the intercourse which occurs between third parties and unincorporated associations, than is the traditional view than an unincorporated association has no rights apart from the personal rights of its individual members. The corporate view is a clearer reflection of the perceptions of both parties to the contract. Members of unincorporated non-profit associations generally do not intend to be liable for sums greater than their subscriptions (which the court recognized in Wise) nor do third parties generally intend to deal with the members individually. An unincorporated association's inability to contract in its own capacity is, to say the least, deceiving. ${ }^{57}$ How can this deception be removed? How can unincorporated associations be given the right to sue and be sued?

\section{A SOLUTION}

\section{A. THE RIGHT TO SUE AND BE SUED AT COMMON LAW 1. DOES IT EXIST?}

It has been suggested that an unincorporated association should have the right to sue and be sued at common law. ${ }^{58}$ Traditionally the courts have recognized only two types of legal entities capable of suing: the human individual and the corporation. ${ }^{59}$ Therefore, one must ask whether or not an unincorporated non-profit association can be recognized as a legal entity at common law.

Sturges in his article "Unincorporated Associations as Parties to Actions" 60 has argued that there is nothing sacred in the term "separate legal entity", and that wherever persons act in a concerted ef fort with the intent that they be treated in concert for certain purposes, they should be considered as a separate legal entity under the name of their association to the extent of their efforts towards those purposes whether or not they are incorporated. He considers it a historical aberration that the courts presently require a corporate body to be statutorily incorporated before it will be given recognition as a separate legal entity. ${ }^{61}$

Sturges gives as the reason the right to sue or be sued was denied unincorporated associations as that it was felt to be a usurpation of the

57. D. Lloyd, supra n. 9 at $409-410$.

58. W.A. Sturges, supra n. 37 at 383.

59. H.A.J. Ford, supran. 1 at 115.

60. W.A. Sturges, supra n. 37 at 383.

61. Id. at 394-396. 
Crown's prerogative to grant corporate status. But, he feels legal identity is a totally different issue.

Being a separate legal entity or not has nothing to do with incorporation. Separate legal entity is, rather, a practical question of behaviour if a group uses a certain name to operate under then it should be allowed to sue and be sued pursuant to that name. It is not sufficient to say an unincorporated association is not a separate legal entity separate from its members merely because it is not incorporated. ${ }^{62}$ Sturges is correct in saying that it is a legal fiction to deny the separate legal identity of unincorporated associations merely because they are unincorporated. ${ }^{63}$ They are as much a separate legal entity as a corporation. But, the courts are not without reason for denying the right of unincorporated associations to sue and be sued. The reason is historical, but it is nonetheless valid.

\section{SHOULD IT EXIST?}

Sturges in his analysis brushes aside royal prerogative over incorporation as insufficient justification for the prevention of an association from suing or being sued: 64

That the present status of the general rule is that of a technical matter of form in our procedure, and that it is the cause of unnecessary inconvenience. That it can well be abolished by the courts of their own motion and suits allowed to be brought in the association name.

Royal prerogative to grant corporate status is not, however, merely a technical matter. It is not simply a rubber stamp process which imposes hardships on parties dealing with unincorporated associations, with no justification. It is a well accepted part of the common law that incorporation depends upon a state grant. ${ }^{65}$ But, although historical in origin, the reason why the royal prerogative has remained a part of our contemporary law is still relevant. The reason is "regulation".

Prior to the Bubble $\mathrm{Act}^{66}$ of 1720 the royal prerogative had become somewhat disused. Numerous companies were formed without royal charter and many of those wishing the legitimacy of a charter purchased them from other companies, of ten with objects entirely different from the new enterprise. ${ }^{67}$ In 1720 the South Sea Company crashed after fantastically high levels of speculation had driven share prices in the company well beyond reasonable levels. The result was large losses, bitterness, and general distrust of corporate bodies. It became apparent to the government that regulation of corporate activities was necessary and the government reaction was the Bubble Act "which made it illegal to form a joint stock company in the future except by means of a royal charter" ${ }^{68}$ Although the Bubble Act was later repealed in 1825 it is that Act which reflects the contemporary reason for the maintenance of the royal prerogative: the regulation of companies. Ever since the Bubble Act

\footnotetext{
62. Id. at 397.

63. Id. at 396.

64. Id. at 405 .

65. L.C.B. Gower, Principles of Modern Company Law (4th ed. 1979) 22.

66. (1719) 6 Geo. 1, c. 18.

67. One of the more common examples cited is of the bank which operated under the charter of a sword blade company, See L.C.B. Gower, supran. 65 at 28.

68. R. Robert, Chartered Companies (1969) 15.
} 
the law has struggled to regulate corporate activities, and this is the common thread which has persisted to the present. Incorporation of a company pursuant to contemporary Companies Acts subjects the enterprise to regulation. Unincorporated for-profit associations, given the right to sue and be sued in their own name, have also been subjected to the collateral obligation of regulation pursuant to the various Partnership Acts. If unincorporated non-profit associations are to be given a common law right of suing and being sued they would in effect be allowed to enjoy all of the advantages of incorporation without any of its attendant liabilities.

\section{B. A PROPOSAL}

A comprehensive solution can best be achieved through statutory intervention. The statute should not only confer the right to sue and be sued upon unincorporated associations, but should also impose upon the associations regulations which the many years of development in company law have shown to be desirable in similar situations. Allowance must be made for the association's non-profit status but it behooves any reformer to take advantage of the wisdom which has been acquired in the development of company law regarding protections that exist between a creditor and a corporate body. ${ }^{69}$ If the solution is restricted to the granting of the right to litigate without subjecting unincorporated non-profit associations to regulation, either by statute or at common law, then problems will remain, such as the liability of the committee personally even where it has reasonably relied on of ficial documents.

The situation is this: at present gross inequities may occur on a procedural basis because of the intermingling of theories in unincorporated non-profit association law. The problems can be avoided by adopting a theoretically consistent view. It is suggested that corporate theory better reflects the expectations of the parties. In order to become theoretically consistent with the corporate view, unincorporated association law must be altered to permit such associations to sue and be sued in their own name. By conferring such a right on an unincorporated association it will, in effect, have gained all the advantages of a corporate body. It is incumbent upon any reformer that the law should also impose the responsibilities that are concurrent with these rights; to do otherwise would be to paint only one half of the picture.

69. Some examples of the company law regulations which an unincorporated non-profit association statute might adopt are: the need for annual financial disclosure, the allowance of change in an association's purpose by the assent of a special majority, or the creation of mandatory schemes for the winding-up of associations. As mentioned above, adaptation of the company law principles will be required in order to compensate for the non-profit status of associations. For instance, when dealing with non:profit associations dedicated to a public benefit it may be preferable that the financial disclosure be made to certain government of ficials rather than the membership. This would avoid the high administration costs of a general disclosure (which would be counter-productive to the advancement of the public benefit) and the inherent difficulty there would be in determining who was a member. Also, it may be necessary with public benefit non-profit associations to require that there be a terminal distribution constraint upon winding-up in order that a contributor's donation be applied as intended. It would be antithetical to allow the present members of a public benefit non-profit to appropriate the accumulated assets of the association upon winding-up when the contributions had been intended to benefit a public purpose and not the members. Therefore a cy-presclause may be necessary. 